\title{
STRATEGI KESANTUNAN BERBAHASA PADA MASYARAKAT BANJAR
}

(POLITENESS STRATEGIES IN BANJAR COMMUNITY)

\section{Rissari Yayuk}

\author{
Balai Bahasa Kalimantan Selatan
}

Pos-el: yrissariyayuk@yahoo.co.id

Diterima: 19 Juli 2016; Direvisi: 03 Agustus 2016; Disetujui: 9 November 2016

\begin{abstract}
This study titled politeness strategies in Banjar community. The problem raised is how a form of politeness strategies in Banjar community. The purpose was to determine the form of politeness strategies in Banjar community. Methods of research on the subject of politeness strategies in Banjar community is using descriptive method. Collecting data in Bamban village of months of February and March 2016. The results of the research is a form of politeness strategies in Banjar community includes attention to what is needed or preferred opponent said, using solidarity or group identity through a greeting or jargon, offer or promise anything, to avoid overlapping, and clowning.
\end{abstract}

Key words: strategy, politeness, Banjar.

Abstrak

Penelitian ini berjudul strategi kesantunan berbahasa pada masyarakat Banjar. Masalah yang diangkat adalah bagaimana wujud strategi kesantunan berbahasa pada masyarakat Banjar. Tujuannya adalah mengetahui wujud strategi kesantunan berbahasa pada masyarakat Banjar. Metode penelitian tentang masalah strategi kesantunan berbahasa dalam masyarakat Banjar ini menggunakan metode diskriptif kualitatif. Pengambilan data di desa Bamban dari tanggal 1 bulan Februari sampai dengan 1 Maret 2016. Penelitian ini menyimpulkan wujud strategi kesantunan berbahasa pada masyarakat Banjar meliputi memperhatikan apa yang dibutuhkan atau disukai lawan tutur, menggunakan solidaritas atau identitas kelompok melalui sapaan atau jargon, menawarkan atau menjanjikan sesuatu, menghindari ketidakcocokan, dan melucu.

Kata Kunci: strategi, kesantunan, Banjar. 


\section{Pendahuluan}

Masyarakat Banjar merupakan penutur bahasa Banjar yang berada di Provinsi Kalimantan Selatan. Masyarakat Banjar adalah bagian dari penduduk Indonesia yang memiliki budaya berbahasa pada umumnya yang terikat adat, agama, dan kepercayaan. Ideham, dkk (2005:165) menyatakan setiap warga masyarakat Banjar sesuai dengan kedudukannya berusaha menaati segala ketentuan yang berhubungan dengan tata kelakuan yang telah digariskan berdasarkan adat, agama, dan kepercayaan.

Lebih lanjut, Ideham dkk (2005:164--170) menyatakan bahwa tata kelakuan berbahasa yang santun dalam masyarakat Banjar ini berlaku dalam lingkungan rumah tangga, pemerintahan, pendidikan, keagamaan, maupun kemasyarakatan dan ekonomi. Anggota masyarakat Banjar ini biasanya memperhatikan bahasanya yang sopan berlandaskan loyalitas dan tenggang rasa. Waktu berbicara memperhatikan usia, status sosial, hubungan kekerabatan, dan jarak keakraban yang bersangkutan.

Berkaitan dengan penggunaan bahasa yang terikat oleh kesantunan ini, masyarakat Banjar tentu memiliki strategi agar mereka dapat berbudaya santun dalam berbahasa. Strategi ini menjadi sarana yang andal dalam rangka menjalin hubungan komunikasi yang lancar dan bebas dari konflik antarpeserta tutur. Penggunaan strategi dalam berbahasa ini akan membentuk sebuah kehidupan sosial yang harmonis antarwarga.

Permasalahannya sekarang, dalam kenyataannya, era globalisasi sekarang telah memengaruhi pola budaya berbahasa masyarakat Banjar, khususnya di daerah perkotaan. Kesantunan berbahasa yang selama ini membudaya secara perlahan telah mengalami pergeseran. Hal ini menyebabkan timbulnya kekhawatiran akan hilangnya secara perlahan namun pasti budaya lokal yang bernilai positif. Oleh sebab itu, dibutuhkan upaya yang bisa menanggulanginya, salah satunya melalui pendokumentasian budaya santun. Pendokumentasian budaya santun ini penting dilakukan salah satunya untuk dunia pendidikan yang dapat menjadikannya sebagai salah satu materi ajar yang bermanfaat bagi generasi muda kelak.

Berdasarkan paparan di atas, penelitian yang menggunakan teori pragmatik ini mencoba mengkaji 
masalah strategi kesantunan berbahasa dalam masyarakat Banjar. Tujuan penelitian adalah untuk mengetahui strategi kesantunan berbahasa dalam masyarakat Banjar. Hal ini berarti diharapkan akan banyak hal yang bisa digali mengenai masalah kesantunan berbahasa yang berkaitan dengan kehidupan sosial. Hymes (dalam Lubis, 2004:84) menyatakan wujud dan strategi kesantunan berbahasa dalam interaksi berbahasa merupakan bagian yang tidak terpisahkan dari sistem sosial.

Penelitian tentang kesantunan berbahasa ini pernah dilakukan oleh peneliti sebelumnya, namun memiliki perbedaan dengan penelitian yang dilakukan peneliti sekarang. Musdalipah (2010) memaparkan kesantunan berbahasa meminta pada bahasa Banjar dan pada tahun 2012 Yayuk meneliti "Maksim Kesopanan dalam Tuturan Penumpang dan Tukang Ojek di Pasar Hanyar Kota Banjarmasin”. Penelitian Musdalipah mengupas tentang kesantunan berbahasa meminta berdasarkan skala Leech. Penelitian Yayuk (2012) mengkaji tentang pelaksanaan maksim kesantunan pada tuturan penumpang dan tukang ojek di Pasar Hanyar. Dua penelitian terdahulu ini mengkaji masalah kesantunan berbahasa dengan fokus dan sumber data yang berbeda dengan penelitian ini.

\section{Kerangka Teori}

\subsection{Pragmatik}

Kridalaksana (1993: 177) menyatakan bahwa pragmatik (pragmatics) adalah ilmu yang menyelidiki pertuturan, konteksnya dan maknanya. Selain itu Tarigan (1986:25) menyatakan bahwa pragmatik adalah suatu telaah makna dalam hubungannya dengan aneka situasi ujaran. Pragmatik diperlukan dalam menganalisis makna yang dipertuturkan oleh penutur disesuaikan dengan situasi ujar. Situasi ujar ini meliputi penutur dan lawan tutur, konteks tuturan, tujuan tuturan, dan tuturan sebagai tindak verbal. Selanjutnya, Levinson (dalam Tarigan, 1986:33) menyatakan bahwa pragmatik adalah relasi antara bahasa dan konteks yang merupakan dasar bagi suatu catatan atau laporan suatu pemahaman bahasa, dengan kata lain telaah mengenai kemampuan pemakai bahasa menghubungkan serta menyerasikan kalimat-kalimat dan konteks-konteks sosial secara tepat. 


\subsection{Kesantunan Berbahasa}

Allan (dalam Wijana, 1996:45) menyatakan bahwa berbahasa adalah aktivitas sosial. Seperti halnya aktivitas-aktivitas sosial yang lain, kegiatan berbahasa baru terwujud apabila manusia terlibat di dalamnya. Di dalam berbicara, penutur dan mitra tutur sama-sama menyadari bahwa ada kaidah-kaidah yang mengatur tindakannya, penggunaan bahasanya, dan interpretasi-interpretasinya terhadap tindakan dan ucapan lawan tuturnya. Setiap peserta tindak tutur bertanggung jawab terhadap tindakan dan penyimpangan terhadap kaidah kebahasaan di dalam interaksi lingual itu.

Berkaitan dengan tuturan yang santun ini, Ellen (dalam Chaer dan Leonie Agustina, 2010:21) menyatakan bahwa kesantunan merupakan salah satu prinsip dalam penggunaan bahasa. Dalam berbahasa, perlu dipertimbangkan perasaan orang lain. Dengan mempertimbangkan perasaan orang lain saat berkomunikasi ini, akan memungkinkan transaksi interaksi sosial berlangsung tanpa mempermalukan (mengancam muka) penutur dan mitra tutur.
Chaer dan Agustina (2010:5) menyatakan bahwa pada umumnya penutur memilih strategi khusus dalam penyusunan kontribusi komunikatif. Penutur memilih alat linguistik yang tepat dalam mencapai strategi pilihan. Alat linguistik yang berbeda berkaitan dengan pemilihan strategi tertentu. Misalnya untuk sebuah permohonan, perintah langsung dianggap sebagai strategi yang tidak santun. Perintah yang tidak langsung dianggap strategi berbahasa yang santun.

Menurut Brown dan Levinson (1987) (dalam Rahardi, 2005:67), kesantunan berbahasa memang sangatlah penting diperhatikan dalam kehidupan sosial untuk menghindari konflik yang mungkin terjadi dalam setiap interaksi komunikasi. Namun, kesantunan dalam bertutur diterapkan secara berbeda pada setiap kebudayaan karena setiap teks tidak bisa terlepas dari konteksnya.

Chaer (2010:172) menyatakan bahwa etika berbahasa erat kaitannya dengan pemilihan kode bahasa, normanorma sosial, dan sistem budaya yang berlaku dalam suatu masyarakat. Etika berbahasa antara lain akan "mengatur " (1) apa yang harus kita katakan pada waktu dan keadaan tertentu kepada 
seorang partisipan tertentu berkenaan dengan status sosial dan budaya dalam masyarakat itu; (2) ragam bahasa apa yang paling wajar kita gunakan dalam situasi sosiolinguistik dan budaya tertentu; (3) kapan dan bagaimana kita menggunakan giliran berbicara kita, dan menyela pembicaraan orang lain; (4) kapan kita harus diam; (5) bagaimana kualitas suara dan sikap fisik

\subsection{Strategi Kesantunan Berbahasa}

Searle (dalam Ibrahim, 1993:27) menyatakan, seseorang tidak akan bertutur tanpa memikirkan lebih dahulu apa yang akan diujarkan. Dalam berbicara, penutur tidak asal bicara, tetapi harus memilih strategi bertutur apa yang paling tepat digunakan untuk sekadar menyampaikan pesan/ informasi saja, tetapi juga membina hubungan sosial dengan penutur. Oleh sebab itu, penutur harus memilih strategi bertutur yang tepat dalam menyampaikan tuturannya diharapkan penutur dapat menyampaikan pesan penutur secara baik tanpa merusak muka (citra diri) atau menyinggung perasaan petutur.

Hymes (dalam Lubis, 2004:84) menyatakan bahwa wujud dan strategi kesantunan berbahasa dalam interaksi antarpenutur dengan petutur berdasarkan satuan pragmatis dan implikasi pragmatis dibangun dengan memperhatikan faktor linguistik dan nonlinguistik. Faktor nonlingustik mencakup latar, penutur, tujuan, isi tuturan, nada dan gaya tutur, sarana, norma dan tipe tutur. Hal ini didasarkan bahwa bahasa merupakan bagian yang tidak terpisahkan dari sistem sosial.

Brown dan Levinson (dalam Gunarwan, 1994:6) menjelaskan bahwa "muka" itu rawan terhadap ancaman yang timbul dari tindak tutur tertentu. Artinya, ada tindak tutur yang cara pengungkapannya atau maksud dari tuturannya yang menyebabkan "muka" terancam, baik pada "muka" penutur maupun "muka" petutur. Tindak tutur mengancam "muka" itulah yang menyebabkan penutur memilih strategi dengan mempertimbangkan situasi atau peristiwa tuturnya, yaitu kepada siapa ia bertutur, di mana, tentang apa, untuk apa dll. Penutur menentukan strategi ini dengan "menghitung" tingkat keterancaman "muka" berdasarkan jarak sosial penutur dengan petutur, besarnya perbedaan kekuasaan di antara keduanya serta status relatif dari jenis tindak tutur yang diujarkan penutur di dalam kebudayaan yang 
bersangkutan. Berdasarkan perhitungan atau pertimbangan itulah, penutur memilih strategi untuk melakukan tindak tutur yang isi atau maknanya sudah ada dalam pikirannya.

\section{Metode Penelitian}

Metode penelitian tentang masalah strategi kesantunan berbahasa dalam masyarakat Banjar ini menggunakan metode diskriptif. Metode ini menggambarkan fenomena yang terjadi pada tuturan yang ada secara empiris. Metode ini merupakan metode yang banyak digunakan dan dikembangkan dalam ilmu-ilmu sosial, termasuk penelitian bahasa karena pada umumnya dilakukan semata-mata hanya berdasarkan fakta atau fenomena yang memang secara empiris hidup pada penuturnya tanpa memperhitungkan benar atau salah. Hal ini sesuai dengan pendapat Djajasudarma (1993:54) dan Moleong (1995:68) yang mengatakan bahwa data yang digunakan bersifat akurat dan alamiah. Data yang dihasilkan berupa deskripsi penggunaaan bahasa penuturnya.

Adapun data penelitian diambil pada masyarakat penutur bahasa Banjar di Desa Bamban, Kabupaten Hulu Sungai Selatan, Provinsi
Kalimantan Selatan. Waktu pengambilan data pada tanggal 1 Februari 2016 s.d. 1 Maret 2016. Berdasarkan hasil di lapangan, data yang diperoleh di waktu satu bulan tersebut sudah memadai untuk dianalisis.

Teknik yang digunakan dalam tulisan ini adalah pengambilan sampel purposive sampling, yaitu teknik pengambilan sampel sumber data dengan pertimbangan tertentu (Sugiyono, 2009:300). Penetapan sampel tidak didasarkan keterwakilan dalam hal jumlah responden (besar sampel), tetapi berdasarkan kualitas atau ciri-ciri responden yang ingin diwakili. Berdasarkan metode dan teknik di atas, penulis menempuh tiga langkah kerja, yaitu tahap pengumpulan data, pengolahan data, dan tahap penyajian hasil analisis data, hal ini sesuai pula dengan yang dimaksudkan Sudaryanto (2003:57). Data yang telah dikumpulkan selanjutnya diperiksa secara selektif berdasarkan permasalahan yang ada, data terpilih ini dianalisis disesuaikan dengan teori pragmatik dan disajikan dengan metode informal atau kata-kata biasa. 


\section{Pembahasan}

\subsection{Strategi Kesantunan Berbahasa Masyarakat Banjar \\ Dalam komunikasi sehari-hari} masyarakat Banjar, ditemukan ragam strategi kesantunan berbahasa. Strategi ini berkaitan dengan strategi kesantunan berbahasa yang dikemukakan Levinson (dalam Rohmadi, 2009: 135--136).

\subsubsection{Memperhatikan apa yang} dibutuhkan, disukai, dan diinginkan lawan tutur

Dalam bertutur, seorang penutur hendaknya selalu memperhatikan apa yang dibutuhkan mitra tutur. Mitra tutur akan merasa senang dan nyaman ketika kebutuhannya diperhatikan penutur.

Data [1]

P : Umaaii hari hujann nah, basinggah hulu kaina kahujanan. Mun kada ku injami paying

'Aduuh hari hujan sekarang, mampir dahulu nanti kehujanan. Kalau tidak aku pinjami payung ya'

MT : Inggih makasiih, satumat lagi sampai, biar sakalian basah ja kadapapa jua nah 'Iya terimakasih, sebentar lagi sampai, biar sekalian saja basahnya tidak apa-apa juga'

Konteks: Tuturan terjadi antara dua warga masyarakat di sebuah desa di kala rintik hujan mendadak turun
Contoh [1] terjadi dalam konteks seorang tetangga atau penutur bahasa sedang melihat tetangganya melewati rumahnya. Kebetulan saat itu hari mau hujan, mendung sangat hitam, gerimis mulai turun. Melihat keadaan tersebut, penutur bahasa menyatakan Umaaii hari hujann nah, basinggah hulu kaina kahujanan. Mun kada kuinjami paying 'Aduuh hari hujan sekarang, mampir dahulu nanti kehujanan. Kalau tidak aku pinjami payung ya'.

Tetangga atau penutur bahasa ini menggunakan strategi kesantunan yang pertama, yakni memperhatikan apa yang dibutuhkan mitra tutur bahasa. Penutur menyatakan bahwa hari akan segera hujan. Dia mempersilahkan mitra tutur untuk singgah ke rumahnya, sebab kalau tidak pasti akan kehujanan. Selain itu, penutur juga akan meminjamkan payung miliknya jika mitra tutur mau melanjutkan perjalanan dalam kondisi hujan.

Mendengar kesantunan berbahasa penutur ini, mitra tutur pun merasa dihargai karena penuttur sebenarnya mengetahui apa yang dibutuhkannya. Akan tetapi, berhubung mitra tutur merasa bahwa sebentar lagi 
dia akan sampai juga di rumahnya, jadi tidak mengapa kalau dia berbasahbasah kena air hujan. Karena itu, dia menolak tawaran penutur seraya mengucapkan terima kasih. Mitra tutur, dengan senyum ramah dan anggukan kepala memberi jawaban Inggih makasiih, satumat lagi sampai, biar sakalian basah ja kadapapa jua nah Iya terima kasih, sebentar lagi sampai, biar sekalian saja basahnya tidak apaapa juga'.

\subsubsection{Menggunakan penanda} solidaritas, identitas kelompok melalui sapaan atau jargon

Penanda solidaritas ini digunakan sebagai salah satu strategi kesantunan positif dalam berbahasa. Penanda solidaritas ini membuat kesetaraan, tanpa ada jarak antara penutur dan mitra tutur.

Data [2]

P : Piyan handak kamana cil, sama lawan ulun kah, ulun handak $k a$ rumah Haji Amat, mun kada umpat ulun ja bakandaraan

'Anda ingin kemana Bi sama dengan saya kah, saya ingin ke rumah Haji Amat, kalau tidak ikut saya saja naik kendaraan'.

MT : Iih pas banar nah Nakkai ikam tawari. Aku handak ka sana jua nah
'Iya kebetulan sekali, Nak kamu tawari. Aku akan ke sana juga nah'

Konteks: Tuturan terjadi kala penutur yang berkendara dan secara kebetulan melewati mitra tutur yang jalan kaki

Data [2] merupakan contoh penutur bahasa menggunakan strategi menggunakan penanda solidaritas, identitas kelompok melalui sapaan atau jargon. Saat itu, penutur bahasa sedang melewati seorang warga desa yang sebaya dengan ibunya. Penutur bahasa ini akan menuju acara perkawinan Haji Amat. Pikiran penutur jangan-jangan mitra tuturnya ini akan menuju tempat yang sama. Oleh karena itu, dia berujar santun Piyan handak kamana cil, sama lawan ulun kah, ulun handak ka rumah Haji Amat, mun kada umpat ulun ja bakandaraan 'Anda ingin kemana Bi sama dengan saya kah, saya ingin ke rumah Haji Amat, kalau tidak ikut saya saja naik kendaraan'. Dalam konteks ini, penutur berujar dengan cara menyapa mitra tutur secara santun.

$$
\text { Penutur pada contoh }
$$
menggunakan penanda solidaritas kata ganti piyan 'kamu', cil 'Bi' dan ulun 'saya'. Penanda kesantunan ini digunakan dalam komunikasi masyarakat Banjar biasanya dari yang 
muda kepada yang tua. Penutur bahasa yang usianya lebih muda dari mitra tutur diaanggap tidak sopan jika menggunakan kata ganti diri dengan sebutan aku'saya'. Demikian pula jika menyapa mitra tutur yang usianya lebih tua tadi dengan sebutan ikam 'kamu'. Sebab jika penutur menggunakan kata sapaan aku dan kamu kepada penutur, maka hal itu dapat dikatakan penutur sombong dan bermaksud membuat jarak yang lebih tinggi dari mitra tutur. Jadi, penanda solidaritas ini memang digunakan penutur sebagai salah satu strategi kesantunan positif dalam berbahasa. Penanda solidaritas ini membuat kesetaraan, tanpa ada jarak antara penutur dan mitra tutur secara santun berdasarkan faktor usia.

Tanggapan mitra tutur terhadap penutur pun terlihat santun pula. Mitra tutur menggunakan penanda solidaritas Nak 'anak' kepada penutur. Iih pas banar nah Nakkai ikam tawari. Aku handak ka sana jua nah 'Iya kebetulan sekali, Nak kamu tawari. Aku akan ke sana juga nah' Mitra tutur juga menerima baik ajakan penutur untuk ikut kendaraan yang dikendarai penutur.
4.2.3 Menawarkan atau menjanjikan sesuatu

Menawarkan atau menjanjikan sesuatu kepada mitra tutur adalah salah satu strategi berbahasa santun. Strategi ini dapat membuat sebuah komunikasi menjadi lancar. Mitra tutur (MT) pun akan mendapatkan keuntungan dari janji ini.

Data [3] MT

: Umai rambutannyalah (sambil tertawa)

'Aduh rambutannya ya'

P : Inggih gampang haja kaina, munnya tuntung $k u$ antari rambutannya

"Iya gampang saja nanti, kalau selesai aku antar rambutannya'

Konteks : Tuturan terjadi antar dua warga yang berada di kebun rambutan

Data [3] ini dituturkan di sebuah kebun warga. Penutur data [3] kebetulan sedang memanen rambutan hasil kebunnya. Tanpa sengaja ada tetangganya atau mitra tutur yang lewat di bawah pohonnya untuk mencari kayu bakar. Penutur melihat tetangganya ada di bawah pohonnya dan langsung berujar Umai rambutannyalah (sambil tertawa) 'Aduh rambutannya ya'. Penutur pun menjawab santun dengan senyum ramah Inggih gampang haja kaina, munnya tuntung ku antari rambutannya 
"Iya gampang saja nanti, kalau selesai aku antar rambutannya'.

Penutur menggunakan strategi kesantunan berbahasa menawarkan atau menjanjikan sesuatu. Penutur menjanjikan kepada mitra tutur kalau nanti dia akan mengantarkan sebagian rambutan hasil kebunnya. Padahal saat itu mitra tutur tidak meminta langsung kepada penutur. Namun penutur berupaya untuk menjalin hubungan sosial yang baik dengan mitra tutur dengan cara menjanjikan sesuatu.

Budaya santun berbahasa dengan strategi menjanjikan sesuatu ini dominan digunakan oleh penutur bahasa Banjar. Biasanya baik sengaja atau tidak, jika ada seseorang sedang melihat aktivitas yang berkaitan dengan panen buah tertentu, sudah menjadi kebiasaan tidak tertulis bagi yang sedang panen akan memberi sebagian kecil hasil panen. Dalam budaya berbahasa ini, mitra tutur mendapatkan keuntungan dari janji yang dilakukan oleh penutur. Penutur telah berupaya menjalin hubungan sosial yang harmonis antarwarga. Sebuah hubungan yang bisa terjalin dengan hal-hal keseharian salah satunya melalui budaya berbahasa santun. Budaya berbahasa yang mulai tergeser penggunaannya di era modern sekarang. Era yang lebih mengunggulkan ego dan kepentingan pribadi daripada kepentingan orang banyak, termasuk dalam hal berbagi rejeki.

\subsubsection{Memberikan pujian kepada mitra tutur}

Pujian yang diberikan penutur kepada mitra tutur akan membuat mitra tutur merasa senang atau bahagia. Mitra tutur merasa dihormati dan diperhatikan.

Data [4]
P : Piyan nih hibat banarlah, sudah sugih baisi anak pada jadian pulang barataan 'Anda ini hebat sekali, sudah kaya mempunyai anak semua pada jadi orang lagi'

MT : Kada juah, ikam nih bisa banar mahimungi urang tuha 'Tidak juga, kamu ini bisa sekali menyenangi orang tua'

Konteks: Tuturan terjadi dalam sebuah ruang tamu salah satu warga

Data [4] terjadi pada sebuah rumah warga. Saat itu penutur sebagai salah satu tetangga mitra tutur sedang datang berkunjung dalam rangka silahturahmi. Di sela perbincangan santai mereka, penutur berujar Piyan nih hibat banarlah, sudah sugih baisi anak pada jadian pulang barataan 'Anda ini hebat sekali, sudah kaya 
mempunyai anak semua pada jadi orang lagi'. Penutur menyatakan bahwa mitra tutur selain memiliki harta yang melimpah juga mempunyai anak-anak yang semuanya menjadi orang terpandang.

Tuturan [4] ini menggunakan strategi kesantunan berbahasa memberikan pujian kepada mitra tutur. Melalui strategi ini penutur secara tidak langsung membuat mitra tutur senang dan bahagia. Mitra tutur merasa dihormati. Mitra tutur merasa kalau ternyata salama ini ada orang yang memperhatikan keberhasilan keluarganya, salah satunya yaitu penutur.

\begin{tabular}{rrr}
\multicolumn{2}{c}{ Kesantunan berbahasa yang } \\
dilakukan penutur adalah sebuah \\
ungkapan pujian yang bisa
\end{tabular}
mengharmonisan sebuah hubungan sosial antarwarga. Warga yang dipuji merasa senang. Mitra tutur berujar Kada juah, ikam nih bisa banar mahimungi urang tuha 'Tidak juga, kamu ini bisa sekali menyenangi orang tua'. Sementara warga yang memuji atau penutur juga menjadikan keberhasilan mitra tutur sebagai sebuah inspirasi dan motivasi yang bisa membuat hidup maju ke depan. Saling mendukung dan merasa senang atas keberhasilan orang lain ini memang penting sebenarnya terus dilestarikan. Kedamaian dan kebahagiaan dalam sebuah masyarakat mudah diwujudkan daripada saling iri dan dengki.

\subsubsection{Menghindari ketidakcocokan sedemikian rupa}

Kesantunan berbahasa akan tercipta kala strategi menghindari ketidakcocokan dalam saat berkomunikasi dilakukan. Strategi ini merupakan salah satu upaya agar komunikasi menjadi lancar.

Data [5]
MT : Maaplah bahamburan nah, kaya kapal pacah 'maaf ya berhamburan, seperti kapal pecah'

P : Umaai kada papa kada usah marasa kada nyaman, sama haja, rumahku gin kaya ini jua.

'Aduh tidak apa-apa tidak usah merasa tidak enak, sama saja rumahku juga seperti ini juga'

Konteks: Tuturan terjadi di sebuah ruangan rumah warga natar dua sahabat

Data [5] terjadi dalam sebuah rumah warga. Penutur saat itu sedang mengunjungi sahabatnya. Saat memasuki ruang tamu, ketika itu dia melihat ruangan tersebut tidak tertata rapi. Tiba-tiba mitra tutur menyatakan bahwa ruangan tamunya seperti kapal 
pecah. Maaplah bahamburan nah, kaya kapal pacah 'maaf ya berhamburan, seperti kapal pecah'

Mendengar pernyataan mitra tutur tersebut, penutur menanggapinya dengan ujaran Umaai kada papa kada usah marasa kada nyaman, sama haja, rumahku gin kaya ini jua. 'Aduh tidak apa-apa tidak usah merasa tidak enak, sama saja rumahku juga seperti ini juga'. Pernyataan penutur menggunakan strategi kesantunan berbahasa menghindari sedemikian rupa ketidakcocokan. Penutur tidak ingin mitra tutur merasa kalau penutur tidak cocok melihat keadaan rumahnya tersebut. Pernyataan penutur pada data [5] merupakan penetralisir perasaan mitra tutur yang mungkin saat itu tidak nyaman sendiri akan keadaan rumahnya dibandingkan rumah penutur.

Ujaran penutur seperti data [5] sekaligus menyatakan kerendahatian. Ujaran ini menunjukkan adanya budaya berbahasa yang santun dalam masyarakat Banjar untuk menghindari ketidakcocokan komunikasi berikutnya.

\subsubsection{Melucu}

Melakukan aktivitas melucu akan membuat komunikasi tidak kaku. Namun, yang harus diperhatikan adalah dilihat pula kondisi tuturan saat itu. Jika aktivitas melucu ini dilakukan kemungkinan besar komunikasi akan terasa hangat.

Data [6]

P Duit ricih kadapapa jua,
sama haja asal duit, asal
jangan baubah jadi daun
Cilai
'Uang receh tidak apa-apa juga, sama saja asal uang, asal jangan berubah jadi daun Bi'

MT : Hiih nah, tahu haja ikam 'Iya nah, tahu saja kamu'

Konteks : Tuturan terjadi di sebuah tempat perbelanjaan tradisional.

Data [6] dituturkan di sebuah pasar tradisional. Saat itu sedang terjadi transaksi jual beli antara penutur dan mitra tutur. Mitra tutur membeli satu kilo ubi kayu. Setelah ubinya diserahkan ke pembeli atau mitra tutur, penuturpun meminta bayaran atas ubi yang dibayarnya tersebut. Mitra tuturpun langsung mengambil dompet dalam keranjang belanjaannya. Setelah beberapa waktu, ternyata mitra tutur hanya memiliki uang receh saja, pembeli tiba-tiba menyerahkan uang pembayaran berupa recehan seribuan dan limaratusan.

Pembeli atau mitra tutur saat itu terlihat kikuk sampai uang recehannya pada berjatuhan ke tanah. Beberapa pengunjung pasar lain di sekitarnya 
melihat kejadian tersebut sejenak menatap pada mitra tutur. Melihat apa yang terjadi pada mitra tutur, penutur pun berujar Duit ricih kadapapa jua, sama haja asal duit, asal jangan baubah jadi daun Cilai 'Uang receh tidak apa-apa juga, sama saja asal uang, asal jangan berubah jadi daun Bi'

Data [6] dituturkan penutur sebagai upaya melucu agar mitra tutur tidak merasa dipermalukan di tengah orang banyak. Penutur mencoba untuk membuat suasana menjadi santai saja. Penutur mengungkapkan bahwa apapun bentuk uang yang diberikan tidak masalah, sebab itu adalah uang juga, namun penutur akan menolak jika tibatiba uang receh tersebut akan berubah menjadi daun. Perubahan bentuk uang yang tidak mungkin terjadi ini menjadi materi lelucon penutur.

Strategi penutur ini memang berhasil, pembeli yang lain tertawa dan mitra tutur juga berubah santai. Hal ini dibuktikan dengan mitra tutur yang dengan santai juga kemudian berujar Hiih nah, tahu haja ikam 'Iya nah, tahu saja kamu'. Transaksi akhirnya berjalan lancar. Mitra tutur pun kemudian berlalu dari tempat itu dengan wajah senang tanpa merasa diperhatikan.

\section{Penutup}

\subsection{Simpulan}

Strategi kesantunan berbahasa meliputi memperhatikan apa yang dibutuhkan atau disukai lawan tutur, menggunakan solidaritas atau identitas kelompok melalui sapaan atau jargon, menawarkan atau menjanjikan sesuatu, menghindari ketidakcocokan, dan melucu.

\subsection{Saran}

Berdasarkan hasil penelitian ini, hendaknya masyarakat Banjar pada umumnya memiliki strategi agar mereka dapat berbudaya santun dalam berbahasa. Strategi ini menjadi sarana yang andal dalam rangka menjalin hubungan komunikasi yang lancar dan bebas dari konflik antarpeserta tutur. Penggunaan strategi dalam berbahasa ini akan membentuk sebuah kehidupan sosial yang harmonis antarwarga.

Bagi peneliti berikutnya yang tertarik untuk mengkaji masalah kesantunan berbahasa, materi ini dapat dijadikan salah satu referensi. Selain itu, yang menjadi harapan peneliti juga kajian tentang bahasa Banjar hendaknya dapat digali lebih dalam lagi dengan berbagai teori bahasa lainnya. 


\section{Daftar Pustaka}

Chaer, Abdul dkk. (2010). Sosiolinguistik. Jakarta: Rineka.

Gunawan, Asim. (1994). Kesantunan Negatif di Kalangan Dwibahasawan Indonesia-Jawa di Jakarta: Kajian Sosiopragmatik. Dalam PELBA 7. Penyunting Bambang Kaswanti Purwo. Yogyakarta: Kanisius.

Ibrahim, Abdul Syukur. (1993). Kajian Tindak Tutur. Surabaya: Usaha Nasional.

Ideham, M. Suriansyah dkk. (2005). Sejarah Banjar. Banjarmasin: Pemerintah Provinsi Kalimantan Selatan.

Kridalaksana, Harimurti. (1993). Pragmatik. Jakarta: Gramedia.

Lubis, Hamid Hasan. (1994). Analisis Wacana Pragmatik. Bandung: Angkasa.

Musdalipah (Ed). (2010). Kesantunan Meminta dalam Bahasa Banjar. Undas. Banjarbaru: Balai Bahasa Banjarmasin.

Rahardi, R. Kunjana. (2005). Pragmatik. Jakarta: Erlangga.

Rohmadi, Muhammad. (2009). Pragmatik Teori dan Analisis. Yogya: Lingkar Media Jogja.

Tarigan, Henry Guntur. (1986). Pengajaran Pragmatik. Bandung: Angkasa.
Wijana, I Dewa Putu. (1996). Pragmatik. Surakarta: Yumna Pustaka.

Yayuk, R. (2012). "Maksim Kesopanan dalam Tuturan Penumpang dan Tukang Ojek di Pasar Hanyar Kota Banjarmasin". Dalam Bunga Rampai Bahasa: 149--174. Banjarbaru: Balai Bahasa Provinsi Kalimantan Selatan. 